\title{
Coupling Effects of Silicate, Iron and Other Various Abiotic Variables on Growth of Two Diatoms, Phaeodactylum Tricornutum and Thalassiosira Weissflogii and Their Silicon Utilization
}

\author{
Aimin Long ${ }^{1,2^{*}}$, Xiaoyong $\mathrm{Yu}^{1,2}$, Qun Xie ${ }^{1,2}$, Xiaofei Song ${ }^{2}$ and Hongwei Xiao ${ }^{2,3}$ \\ ${ }^{1}$ University of Chinese Academy of Sciences, Beijing, 100049, China \\ ${ }^{2}$ LTO laboratory, South China Sea Institute of Oceanography, Chinese Academy of Sciences, Guangzhou, 510301, China \\ ${ }^{3}$ Laboratory of Atmospheric Environment, East China University of Technology, Nanchang, 330013, China
}

\begin{abstract}
Received: November 20, 2017; Accepted: December 13, 2017; Published: December 26, 2017
*Corresponding author: Aimin Long, University of Chinese Academy of Sciences, Beijing, 100049, LTO laboratory, South China Sea Institute of Oceanography, Chinese Academy of Sciences, Guangzhou, 510301, China, E-mail: longam@scsio.ac.cn
\end{abstract}

\begin{abstract}
The effects of various Abiotic factors, including concentrations of silicate and iron, temperature, light intensity and salinity of media on two purebred red tide diatoms, Phaeodactylum tricornutum and Thalassiosira weissflogii were investigated through single and full factorial experiments. The single-factor experiments showed diatom Phaeodactylum tricornutum had the fastest growth rate with initial silicate concentration of $200 \mu \mathrm{mol} \cdot \mathrm{L}^{-1}$, initial iron content of 10 $\mu \mathrm{mol} \bullet \mathrm{L}^{-1}$, environmental temperature of $20^{\circ} \mathrm{C}$, and light intensity of $231.25 \mu \mathrm{mol}$ photons $\bullet \mathrm{m}^{-2} \bullet \mathrm{s}^{-1}$ respectively. Thalassiosira weissflogii grew fastest when initial silicate concentration was $250 \mu \mathrm{mol} \bullet \mathrm{L}^{-1}$, initial iron concentration was $10 \mu \mathrm{mol} \cdot \mathrm{L}^{-1}$, temperature of $30^{\circ} \mathrm{C}$ light intensity of $231.25 \mu \mathrm{mol}$ photons $\bullet \mathrm{m}^{-2} \bullet \mathrm{s}^{-1}$. From full factorial experiments, the main factors affecting Phaeodactylum tricornutum were iron concentration, temperature, the coupling effect of temperature and light intensity, and the coupling effect of temperature and iron concentration. The main factors affecting Thalassiosira weissflogii were temperature, the coupling effect of temperature and iron concentration, and the coupling interaction of silicate and iron. Silicates, iron ions and the coupling effects of temperature and silicate are the main factors affecting the production of biosilicon in Phaeodactylum tricornutum; and temperature, iron and the coupling effect of silicate and iron ions were the main factors influencing biosilicon produced by Thalassiosira weissflogii.
\end{abstract}

Keywords: coupling effect; Phaeodactylum tricornutum, Thalassiosira weissflogii; silicon utilization;

\section{Introduction}

Silicon, the $2^{\text {nd }}$ richest element in the earth's crust, usually presents as dissolved monomer $\mathrm{Si}(\mathrm{OH})_{4}$ in seawater, indispensable for marine diatoms which are responsible for about $40 \%$ global primary production $[51,15,40]$. Marine organisms especially diatoms, radiolarians and siliceous sponges, consume inorganic silicate in seawater and produce biogenic silica, which is the primarily path for silicate removal from seawater. $\mathrm{Si}(\mathrm{OH})_{4}$ is regenerated through oxidation and decomposition of biological residues [14].

Iron, although in the crust the fourth element of abundance, has very low concentration in seawater due to its extremely solubility and easily being absorbed on the particulate matter surface in ocean. It plays an important role in phytoplankton's physiological activities, such as electron transportation, oxygen metabolism, nitrogen fixation, photosynthesis and respiration $[25,19]$. Iron receives more attention than other trace elements because $40 \%$ of the world ocean has been thought to be Fe limited [37]. Some iron can reach surface seawater with upwelling [48] and provide trace metal nutrition for coastal phytoplankton, while only dissolved iron is biologically effective [28,3]. Iron demand by marine phytoplankton is very high compared to its low content, indicating that iron may be one of limiting factors in ocean $[20,5]$.

Iron deficiency has been considered to be the main reason for low biomass of phytoplankton in the high-nitrogen-lowchlorophyll (HNLC) area [17,2]. The limiting effect of iron on marine primary production has been testified by some field experiments $[4,34]$. And some laboratory culture experiments also seem to confirm the results of the iron fertilizing experiment in the wild [8]. For instance, growth rate of Thalassiosira weissflogii and Prorocentrum minimum was significantly limited when iron concentration is less than $100 \mathrm{pM}$ in culture experiments [47].

The researchers found some very interesting phenomena concerning iron restriction on marine phytoplankton. For example, under iron limiting conditions, phytoplankton consumption of silicon is much higher than nitrogen, resulting in a common restriction of iron and silicon $[26,13,17]$. Iron and light 
had co-limiting effect on the growth of phytoplankton in areas with low iron inputs such as HNLC area [11]. However, due to the difficulty in identifying these factors, the phenomenon of the joint limitation of iron, silicon and other factors has not attracted enough attention as they deserve $[49,50,24]$. In the present work, we try to focus on the coupling effect of silicate and iron on the growth of Phaeodactylum tricornutum and Thalassiosira weissflogii through single and full factor experiments respectively, and to further analyze and identify the effects of different Abiotic factors, including silicate, iron, temperature, light intensity, salinity. In single factor experiment, there is only one factor is changed and the rest of the test factors remain unchanged, the specific role and influence of this factor is determined by observing the change of experimental system caused by changing this factor. The main purpose of single-factor experiment is to prepare the orthogonal test and provide a reasonable range of data for orthogonal experiment. Full factorial experiment design is involved in all levels of the experimental factors which are comprehensively combined to form different experimental conditions. Two or more independent experiments are repeated under these conditions. The greatest advantage of design is that a large amount of information can be obtained to accurately assess the size of the main effects of each factor and the magnitude of interactions between factors. Its biggest drawback is that it needs the most experiments and consumes more manpower, material resources and time.

\section{Materials and Methods}

\section{Algae cultivation}

Purified marine diatoms Phaeodactylum tricornutum and Thalassiosira weissflogii were obtained from marine algae center, State Key laboratory of coastal marine environment in Xiamen University, China. Both diatoms are harmful red tide algae and ubiquitous in Chinese coastal sea and with different physiological characteristics and silicate utilization rate $[43,35]$. The diatoms were cultivated in $\mathrm{f} / 2$ medium $[23,22]$ with ameliorated nutrient contents to meet experimental requirements. The medium was prepared with artificial seawater configured according to the recipe of MBL [1]: $24.72 \mathrm{~g} \bullet \mathrm{L}^{-1} \mathrm{NaCl}, 0.67 \mathrm{~g} \bullet \mathrm{L}^{-1} \mathrm{KCl}, 1.36 \mathrm{~g} \bullet \mathrm{L}^{-}$ ${ }^{1} \mathrm{CaCl}_{2} \bullet 2 \mathrm{H}_{2} \mathrm{O}, 4.66 \mathrm{~g} \bullet \mathrm{L}^{-1}, \mathrm{MgCl}_{2} \bullet 6 \mathrm{H}_{2} \mathrm{O}, 6.29 \mathrm{~g} \bullet \mathrm{L}^{-1}, \mathrm{MgSO}_{4} \bullet 7 \mathrm{H}_{2} \mathrm{O}$ and $0.18 \mathrm{~g} \bullet \mathrm{L}^{-1} \mathrm{NaHCO}_{3}$. Artificial seawater was sterilized under $126^{\circ}$ Cfor 40 minutes, adjusted to $\mathrm{pH} 8.0$ with $\mathrm{HCl}$ or $\mathrm{NaOH}$ solution, and kept at $4^{\circ} \mathrm{C}$ as stock solution. The stock solution of artificial seawater was added to cultivation medium immediately after being filtration sterilized in order to avoid precipitation of silicate under high pressure and denaturalization of thiamine hydrochloride, biotin and Vitamin B12 under high temperature.

The diatoms were inoculated in $500 \mathrm{~mL}$ polycarbonate conical flask with $300 \mathrm{~mL} \mathrm{f} / 2$ medium and cultivated in light incubator under following conditions: temperature $21 \pm 0.5^{\circ} \mathrm{C}$, light intensity $81.25 \mu \mathrm{mol}$ photons $\bullet \mathrm{m}^{-2} \bullet \mathrm{s}^{-1}$, light : dark cycle $12 \mathrm{~h}: 12 \mathrm{~h}$, and salinity $30 \%$. In the process of culture, algae cells growth was observed daily, and subculture was carried out regularly to check whether the cells are stained or contaminated with harmful organisms under microscopic.

Algae cells were harvested in the exponential period, centrifuged under $3000 \mathrm{rpm}$ for 10 minutes and cleansed by $0.4 \mathrm{~mol} \cdot \mathrm{L}^{-1} \mathrm{NaCl}$ solution three times to reduce the effect of residual nutrients on the next culture medium. Diatom cells was acclimated in iron-starvation status for 2 weeks before used in iron specific experiments to eliminate the influence of iron adsorbed by diatom cells.

\section{Experimental scheme}

In order to investigate various Abiotic variables including silicate, iron, temperature, light intensity, salinity and their interaction effects on diatoms growth through single and full factorial experiment respectively. In single factorial experiments, we set up 5 silicate $\left(50,100,150,200,250 \mu \mathrm{mol} \cdot \mathrm{L}^{-1}\right)$ and iron(5, 10 , $100 \mathrm{nmol} \bullet \mathrm{L}^{-1}, 1 \mu \mathrm{mol} \bullet \mathrm{L}^{-1}, 10 \mu \mathrm{mol} \bullet \mathrm{L}^{-1}$ ) concentrations, and 5 temperature $\left(10^{\circ} \mathrm{C}, 15^{\circ} \mathrm{C}, 20^{\circ} \mathrm{C}, 25^{\circ} \mathrm{C} 30^{\circ} \mathrm{C}\right)$ levels, 5 light intensities $\left(81.25,112.5,187.5,231.25,250 \mu \mathrm{mol}\right.$ photons $\bullet \mathrm{m}^{-2} \bullet \mathrm{s}^{-1}$, equivalent to $6000,9000,15000,18500,20000$ lux respectively), and 5 salinity (15\%o, 20\%o, 25\%o, 30\%o, 35\%o) levels are taken into account as well.

In full factorial experiment, initial levels of silicate, iron, temperature, light intensity and salinity were setup using Minitab for statistical analysis $(\mathrm{P}<0.05)$ as shown in table 1 . The low level and the high level of each factor presented as "L" and "H", respectively. Each match of two factors could be performed under four kinds of matches ("HH", "HL", "LH", "LL”) to investigate their interaction effects comprehensively.

\section{Cultivation condition parameter determination}

Temperature and light intensity of the culture medium are set directly by RXZ-300 illumination incubator equipped with Smart artificial climate box, calibrated by thermometer and XYIIII illuminance meter (Hangzhou, China) respectively before experiment. The salinity of culture solution was determined by BEC-540 multi-parameter salinity meter (Dalian, China).

\section{Silicate and bio-silicon analysis}

Samples for silicate measurement were pretreated in laboratory according to guidelines of sea monitoring issued by State Oceanic Administration, People's Republic of China (HY147.1-2013). Silicate ( $\mathrm{SiO}_{4}{ }_{4}^{2-}$ ) was determined with a Scalar San Plus Auto-Analyzer following Joint Global Ocean Flux Study (JGOFS) protocols by Knap et al. (1996).

Bio-silicon was analyzed at the end of cultivation in order to investigate the utilization efficiency of diatom cells on silicate. Subsample of $30 \mathrm{~mL}$ algal culture medium was filtered through $0.2 \mu \mathrm{m}$ polycarbonate membrane (Millipore, USA) at the end of cultivation. The membranes were folded and put into $50 \mathrm{~mL}$ plastic centrifuge tube, extracted for 10 minutes in a $95^{\circ} \mathrm{C}$ water bath after adding $10 \mathrm{~mL}$ of $0.2 \mathrm{~mol} . \mathrm{L}^{-1} \mathrm{NaOH}$ solution. The extract is cooled to room temperature, $\mathrm{HCl}$ neutralized and centrifuged, and the content of silicates was determined then. 


\section{Algal cells counting}

Diatom cells were counted every other day at a fixed time after being fixed and dyed using Lugol solution, the cell count was carried out with blood cell counting plate when the cell density was greater than 100000 cells $\bullet \mathrm{mL}^{-1}$, otherwise the cell count is completed under the Nikon-YS100 optical microscope. Every sample was counted for 3 replicates and the average value was orientated $(\mathrm{RE}<15 \%)$.

\section{Quality control and data process}

The chemical reagents used in our experiments are all analytically pure. All wares used for sample collection and storing were soaked in $10 \%$ hydrochloric acid solution for 7 days and then dried after being washed by deionizer water thoroughly. All cleaning procedures were performed in a class-100 clean laboratory. All tests were carried out in triplicate, and a one-way analysis of variance (ANOVA) and full factorial analysis were performed using Minitab for statistical analysis. Differences were considered statistically significant when $\mathrm{p}<0.05$.

\section{Results}

\section{Effects of temperature, light intensity, and salinity on the growth of two diatoms}

Growth of Phaeodactylum tricornutum and Thalassiosira weissflogii under different temperature, light intensity, and salinity were investigated separately in single factorial experiments, and the results were shown in figure1. It was found that the optimum
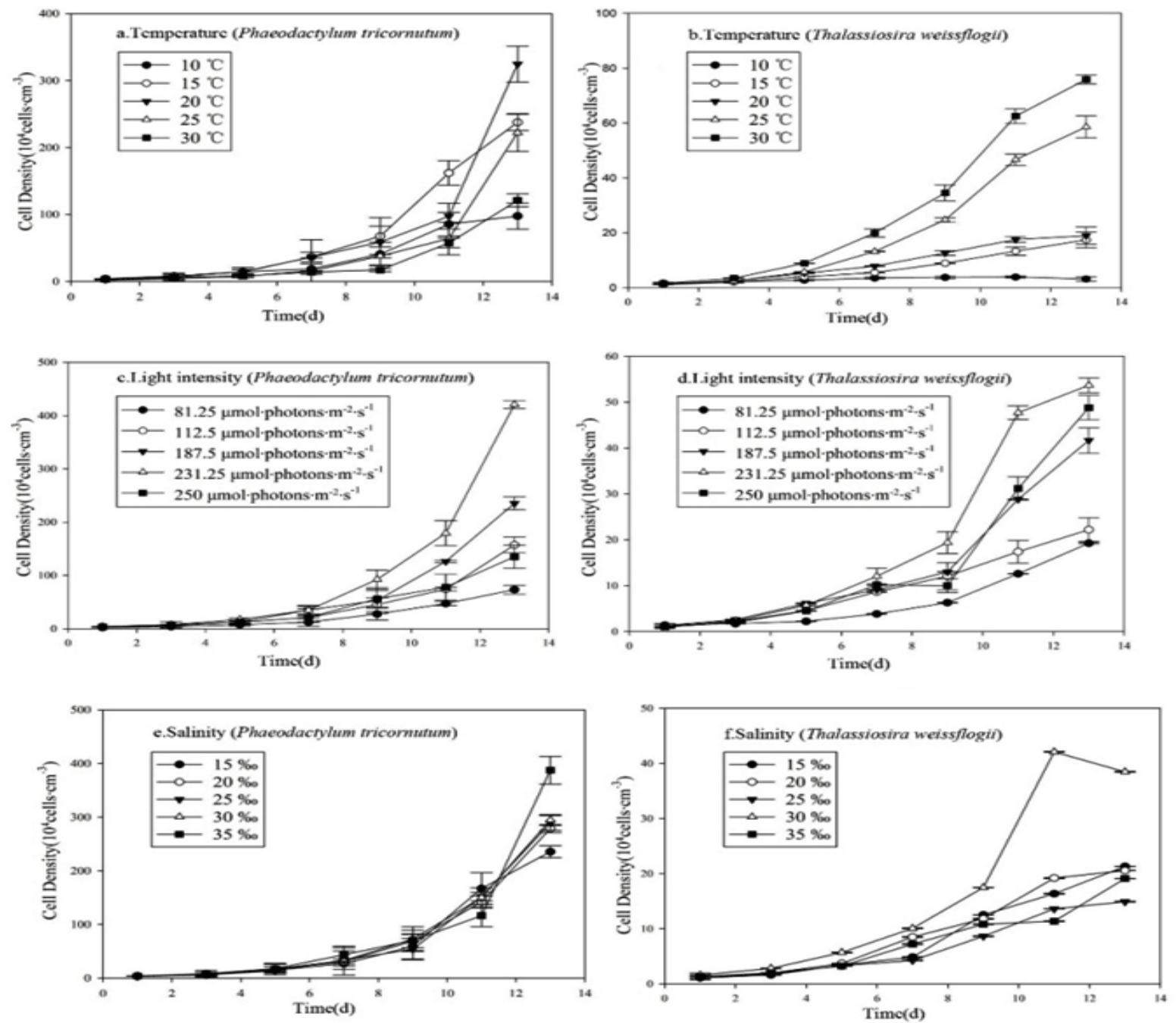

Figure 1: Effects of temperature (a, b), light intensity (c, d), and salinity (e, f) on the growth of Phaeodactylum tricornutum (a, c, e) and Thalassiosira weissflogii $(\mathrm{b}, \mathrm{d}, \mathrm{f})$ 
temperature range for Phaeodactylum tricornutum growth was 15 ${ }^{\circ} \mathrm{C}$ to $25^{\circ} \mathrm{C}$, and the most suitable temperature was $20^{\circ} \mathrm{C}$, at which the cell density could reach $3.25 \times 10^{6}$ cells $\bullet \mathrm{mL}^{-1}$. As for diatom Thalassiosira weissflogii, the optimum temperature was $30^{\circ} \mathrm{C}$, higher than Phaeodactylum tricornutum. At this temperature, its maximum cell density reached $7.59 \times 10^{5}$ cells $\bullet \mathrm{mL}^{-1}$. Both diatom cells had a relatively slower growth rate and lower cell density outside the proper temperature.

Both diatom algae's seemed had same optimum light intensity $231.25 \mu \mathrm{mol}$ photons $\bullet \mathrm{m}^{-2} \bullet \mathrm{s}^{-1}$ for growth as our single factorial experiments revealed. In this light intensity, the cell density of Phaeodactylum tricornutum and Thalassiosira weissflogii at exponential stage amounted to $4.21 \times 10^{6}$ cells $\bullet \mathrm{cm}^{-3}$ and $5.37 \times 10^{5}$ cells $\bullet \mathrm{cm}^{-3}$ respectively. Either insufficient or excessive irradiance inhibited the growth of diatom cells, the slowest growth of two diatoms appeared under light intensity $81.25 \mu \mathrm{mol}$ photons $\bullet \mathrm{m}$ ${ }^{2} \cdot \mathrm{S}^{-1}$.

It was revealed from figure1 that Phaeodactylum tricornutum was seemly less sensitive to salinity than Thalassiosira weissflogii. There was no obvious difference of growth rate and cell density of Phaeodactylum tricornutum under various salinity conditions in the early days of experiments. The effect of salinity on the growth of algae cells did not begin until 13th day, when the algae cells density in the medium with salinity of $35 \%$ was obviously higher than in culture solutions with other salinities. The cell density maximized $3.87 \times 10^{6}$ cells $\bullet \mathrm{mL}^{-1}$ under salinity $35 \%$ and minimum cell density was $2.36 \times 10^{6}$ cells $\bullet \mathrm{mL}^{-1}$ under salinity 15\%o. For diatom Thalassiosira weissflogii, the effect of salinity on cells growth was another. The cells had a relatively different growth rate under different salinity conditions, and the cell density maximized $3.85 \times 10^{5}$ cells $\bullet \mathrm{mL}^{-1}$ on 11 th day under salinity $30 \%$, significantly higher than other four groups.

\section{Effects of silicate and iron on the growth of two diatoms}

Growth of two diatoms, Phaeodactylum tricornutum and Thalassiosira weissflogii under different silicate and iron conditions was revealed in figure 2. Diatom growth was obviously hindered under conditions of silicate deficiency. With the increasing of silicate concentration, the growth rate of Phaeodactylum tricornutum and Thalassiosira weissflogii were boosted significantly. At exponential stage, cell density of Phaeodactylum tricornutum reached $5.32 \times 10^{6}$ cells $\bullet \mathrm{mL}^{-1}$ under initial silicate concentration $200 \mu \mathrm{mol} \bullet \mathrm{L}^{-1}$, while cell density of Thalassiosira weissflogii reached $1.96 \times 10^{6}$ cells $\bullet \mathrm{cm}^{-3}$ under initial silicate concentration $250 \mu \mathrm{mol} \bullet \mathrm{L}^{-1}$.

The inhibitory effect of low concentration of iron on these two diatoms growth was also evident. In iron concentration 5 $\mathrm{nmol} \bullet \mathrm{L}^{-1}, 10 \mathrm{nmol} \bullet \mathrm{L}^{-1}$ and control group, the growth of algal cells was almost stagnant, while the increase of iron concentration significantly accelerated the growth of algal cells. Algal cell density of Phaeodactylum tricornutum and Thalassiosira weissflogii reached maximum under the same initial iron concentration 10 $\mu \mathrm{mol} \bullet \mathrm{L}^{-1}$, amount to $5.07 \times 10^{6}$ cells $\bullet \mathrm{mL}^{-1}$ and $7.96 \times 10^{5}$ cells $\bullet \mathrm{mL}^{-1}$ respectively.
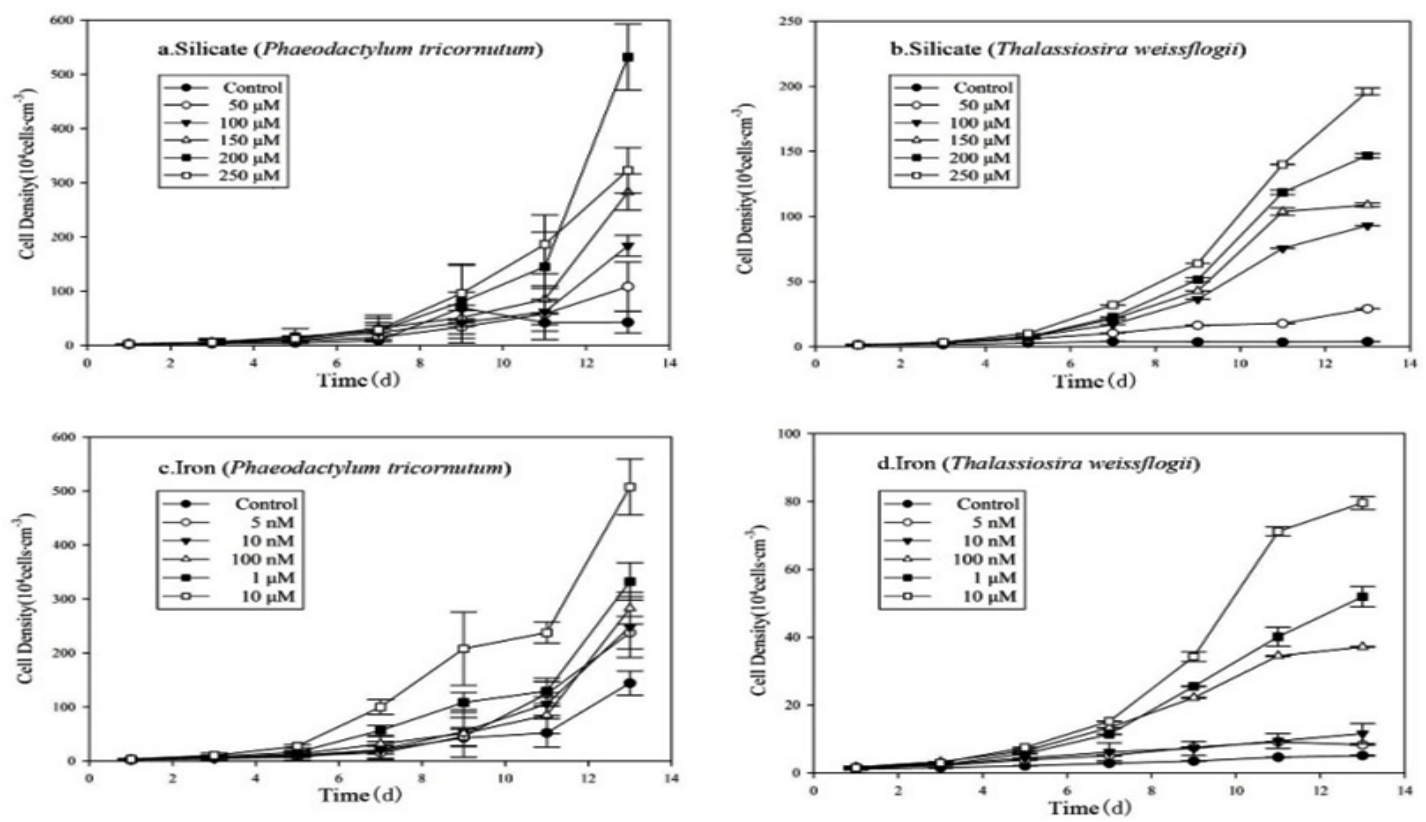

Figure 2: Effects of silicate (a, b), and iron (c, d) concentration on the growth of Phaeodactylum tricornutum (a, c) and Thalassiosira weissflogii (b, d) 


\section{Interactive effect tests}

Full factorial experiments were based on the results of single factorial experiments and the significant tests using Minitab analysis. The full factorial experimental result was shown with significant testing and interaction effect diagrams. In significant testing plots, points obviously deviated from straight line represented the significant effect, and the points near the line or on the line indicated the effects were not obvious. In interaction plots, intersecting of two lines indicated two factors were interactive, while parallel of two lines indicated the two factors were not interactive.

Figure (3a) revealed the interaction effects of temperature, light intensity, salinity and iron contents on cell density of Phaeodactylum tricornutum, and no interaction effect of silicate and iron was found. The specific performances of these interactive effects were shown in figure (3c) in detail. High temperature inhibited the growth of Phaeodactylum tricornutum in all interaction designs, while high iron concentrations significantly boosted the growth of diatom cells in all interaction designs. The coupling effects of low temperature and high iron concentration was relatively obvious. While the coupling effect of temperature and light intensity was not significant, and high light intensity inhibited the diatom cells growth slightly at high temperature indeed. As to biogenic silica contents diatom Phaeodactylum tricornutum cells, the interaction of temperature and silicate, temperature and iron had significant affects figure (3b). The interactive effect of temperature and contents of silicate and iron was that when temperature remained constant, the increase of iron concentration obviously promoted the biological uptake of silicate by algal cells, and this coupling effect was even more obvious in low temperature environments. Although the increase of silicate contents obviously promoted the synthesis of bio-silicon, the effect of the stimulant was more significant in relative high temperature. As shown in figure (3d), environmental temperature, iron concentration, and the coupling effect of temperature and light, temperature and iron contents had significant influence on the growth of algal cells. The decrease of temperature and the increase of iron concentration were beneficial to the growth of algal cells. The effect of light on algal cell concentration was not obvious at low temperature, but when the temperature rose, the increase of light intense significantly inhibited the growth of algae cells.
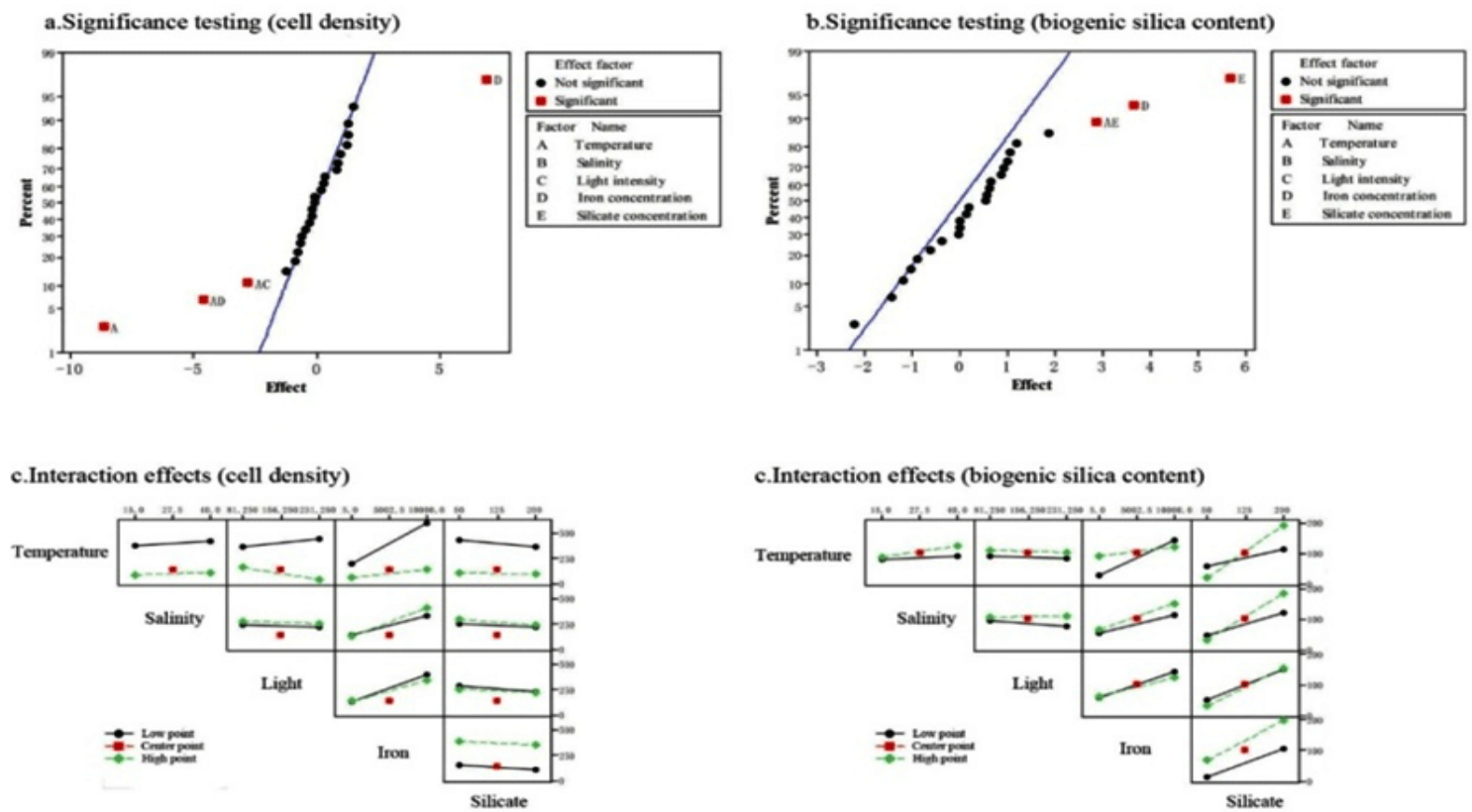

Figure 3: Significance testing (a, b), and interaction effects (c, d) of various factors on cell density and biogenic silica content of Phaeodactylum tricornutum

The results of full factorial experiments on the growth of diatom Thalassiosira weissflogii, and their bio-silicon were shown in figure 4. It was found that the final concentration of algal cell culture was significantly influenced by the coupling of temperature and silicate concentration, iron concentration and silicate concentration, and the temperature itself figure

4(a). At low temperature, there was no significant effect of silicate contents on diatom cells concentration, while with the increasing temperature, algal cells concentrations decreased. When silicate concentrations were at relatively low level, raising the temperature was good for the growth of algal cells. On the contrary, when silicate in environment was at a high level, the 
effect of temperature on the growth of algae cells was not obvious. When iron concentration in culture solution was low, diatom cells concentration decreased obviously with increasing silicate contents. And the increasing of silicate concentration did not significantly affect the concentrations of algal cells in the medium when iron concentration was relatively high figure 4(c). It could be seen from figure 4(b) that the factors that had a significant influence on the content of diatoms Thalassiosira weissflogii cell bio-silicon included temperature, iron concentration and the coupling effect of iron concentration and silicate concentration. The increase of the temperature and iron concentration in the medium was beneficial to the increase of the contents of bio- silicon in algal cells. As revealed in figure 4(d), the silicate and iron concentration coupling effected algal cell bio-silicon and specific performance of the coupling effects were as follows: when the concentrations of iron was high, the increase of silicate was beneficial to the formation of bio-silicon in algal cells, when the iron concentration was in a low state, bio-silicon content decreased with the increasing of silicate concentration; when the concentration of silicate was low, the influence of iron on the formation of bio-silicon was not obvious. In the condition of high silicate, the increase of iron concentration obviously contributed to the increase of the content of bio-silicon in algal cells.
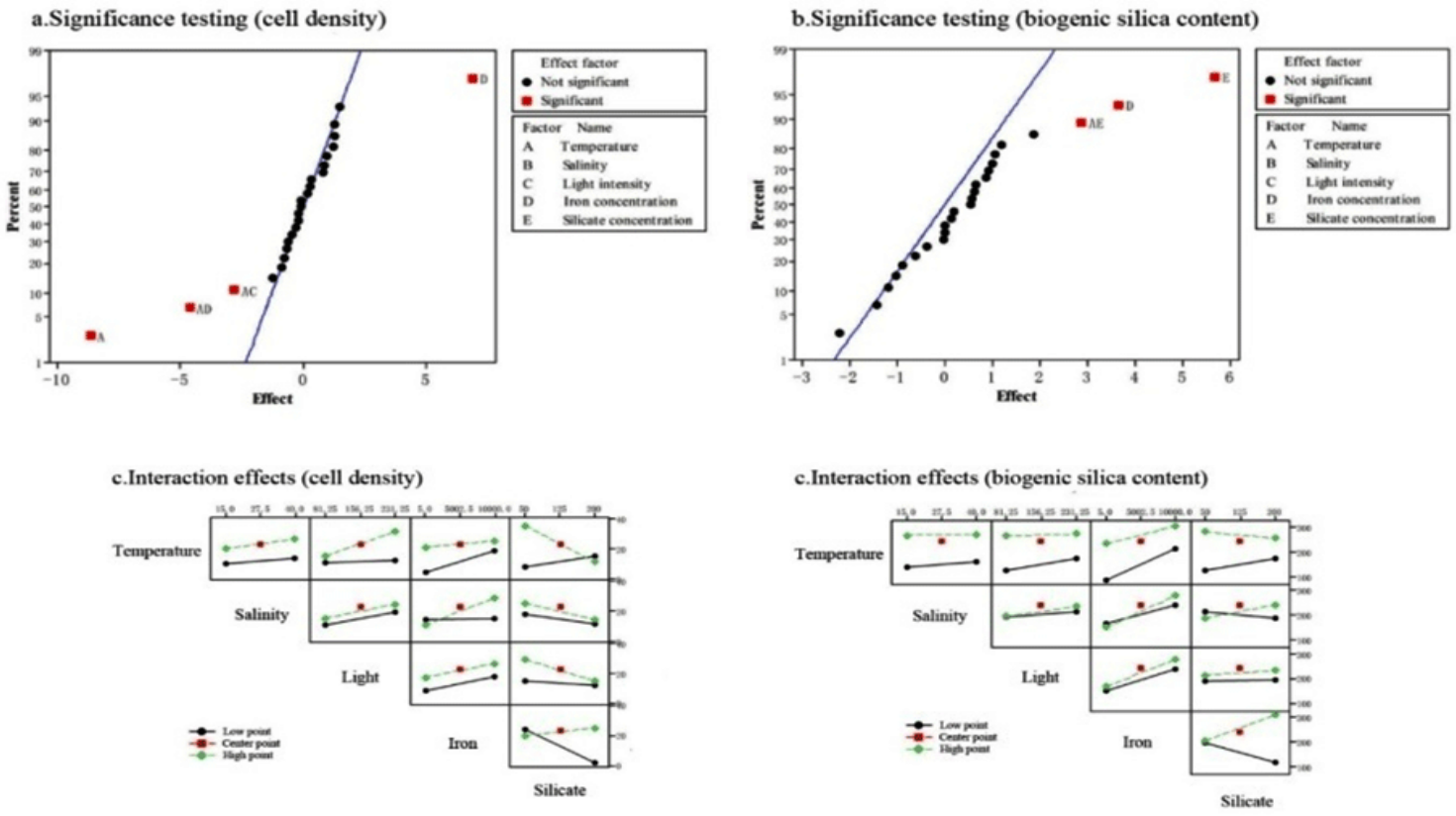

Figure 4: Significance testing (a, b), and interaction effects (c, d) of various factors on cell density and biogenic silica content of Thalassiosira weissflogii

In general, the effects of various factors and their coupling action on both diatoms Thalassiosira weissflogii and Phaeodactylum tricornutum can be revealed by full factorial experiments as the present work. Our experiments indicated that temperature, iron concentration, the coupling of temperature and iron concentration, and the coupling of temperature and light intensity had obvious effect on growth of Phaeodactylum tricornutum, and the order of the magnitude of these effects was iron concentration, temperature, the coupling of temperature and iron concentration, the coupling of temperature and light intensity. While silicate concentration, iron concentration, and the coupling of temperature and silicate concentration had significant effect on the bio-silicon concentration in cells of diatoms Phaeodactylum tricornutum, the order of effects magnitude was silicate contents, iron contents, the coupling of temperature and silicate concentration. In case of Thalassiosira weissflogii, the factors in order of influence size that significantly affected its growth were the coupling iron and silicate concentration, the coupling of temperature and iron concentration, and temperature. And the factors in order of influence size that obviously affected its biosilicon concentration were temperature, iron concentration, and the coupling iron concentration and silicate concentration.

\begin{tabular}{|c|c|c|}
\hline \multirow{2}{*}{ Table 1: Initial factorial levels for full factorial experiment } \\
\hline \multirow{2}{*}{ Factorial } & \multicolumn{2}{|c|}{ Initial factorial levels } \\
\cline { 2 - 3 } & High(H) & Low(L) \\
\hline Temperature & $25^{\circ} \mathrm{C}$ & $15^{\circ} \mathrm{C}$ \\
\hline Salinity & $30 \%$ & $15 \%$ \\
\hline Light intensity & $231.25 \mu \mathrm{mol} \mathrm{photons} \cdot \mathrm{m}^{-2} \cdot \mathbf{s}^{-1}$ & $81.25 \mu \mathrm{mol} \mathrm{photons} \cdot \mathrm{m}^{-2} \cdot \mathbf{s}^{-1}$ \\
\hline $\begin{array}{c}\text { Iron } \\
\text { concentration }\end{array}$ & $10 \mu \mathrm{M}$ & $5 \mathrm{nM}$ \\
\hline $\begin{array}{c}\text { Silicate } \\
\text { concentration }\end{array}$ & $200 \mu \mathrm{M}$ & $50 \mu \mathrm{M}$ \\
\hline
\end{tabular}




\section{Discussion}

Different phytoplankton have different suitable growth conditions, they show different growth and adaptation status under different environment conditions. As shown in our experiments, in a certain rang, both diatoms Thalassiosira weissflogii and Phaeodactylum tricornutum grew rapidly with increasing temperature, illumination and salinity, increasing the concentration of algal cells in medium, but the trend varied with different algae kinds and different environmental factors. For instance, the final density of Thalassiosira weissflogii cells increased with the increase of temperature, reaching the maximum at $30^{\circ} \mathrm{C}$. The main reason for the increase of cell density is that the high temperature has caused higher enzymatic activity, higher photosynthetic rate and higher nutrient uptake [42]. However, the increasing of algal Phaeodactylum tricornutum cell density with temperature behaved in another way. Final cell density reached maximum at a moderate temperature, not the highest temperature. This phenomenon may be attributed to the rapid growth of algal respiration in high temperature conditions $[52,33]$. Generally the largest growth rate of algae is about 0.4 2 generations per day, when light and nutrients in saturated condition, in a certain range, the temperature rises every 10 degrees, phytoplankton growth rate will be more than doubled. The researchers found that diatoms adapted to a wide range of temperatures and were able to grow well between $15^{\circ} \mathrm{C}$ to $35^{\circ} \mathrm{C}$, but grew best at $20^{\circ} \mathrm{C}$ to $30^{\circ} \mathrm{C}$. This is basically in line with our experimental results.

Since light serves as the energy source for photosynthesis, light limitation is regarded as one of major reasons for low phytoplankton biomass, and light intensity and duration are also considered to be determining factors in the degree of photosynthetic activity [24]. In addition, light intensity is considered to regulate the uptake and utilization of nutrients by phytoplankton [10]. Experiments have shown that light intensity can be a major factor in controlling diatoms growth in good mixing conditions and in nutrient-rich waters [46]. As with temperature, the growth of these two diatoms had slightly different manifestations of light intensity response. Our experiment found that the final algal cell density of both diatoms increased with the enhancement of illumination except for the group with the strongest light conditions $(250 \mu \mathrm{mol}$ photons $\bullet \mathrm{m}^{-2} \bullet \mathrm{s}^{-1}$ ). In other words, in a certain range, as the light intensity increase, the photosynthetic rate of algal cells increase, till at the compensation point when the rate of photosynthesis and respiratory is equivalent. As light intensity continues to strengthen, the rate of photosynthesis will gradually decrease, and the phytoplankton will exhibit photo inhibition effect after the light saturation (Chai, 2009).

The two species of diatom algae in our experiment showed strong salinity adaptability, even if their growth rate had different response to the change of salinity condition. Cell density of Thalassiosira weissflogii was found to reach its maximum between salinity $25-35 \%$ [18], which is very similar to our experimental results. The effect of salinity on algae growth is mainly that salinity can affect the osmotic pressure of algal cells, uptake of nutrients and suspension of algal cells themselves [44]. Because both of these two diatoms have considerable salinity adaptability, they have a wide distribution from offshore to open sea.

Diatoms need silicate as substrate to meet their growth requirements, especially to produce frustules. The silicon demand of different species of diatom mainly depends on their differences in physiology [24]. Therefore it is reasonable that high cell density can be found in high silicate cultures as our experiments. Iron is another limiting factor for marine diatoms $[20,5]$. Iron is essential for phytoplankton, involved in cellular processes such as photosynthesis [19]. The importance of iron in photosynthesis stems from its high concentrations in the photo system I and II and the cytochrome $\mathrm{b}_{6}$ f complex [41]. Iron deficiency strongly influence electron transport kinetics, reduce the efficiency in electron transfer and partial inhibit the photo system [38]. As shown in our experiments, final cell density of both Phaeodactylum tricornutum and Thalassiosira weissflogii increased with the amount of iron added to the medium, and there was a critical concentration of iron that allowed the algae to grow into the exponential phase. It was also found that different species of algae cells had different iron demands and different tolerance for iron deficiency. Unlike Phaeodactylum tricornutum, Thalassiosira weissflogii cells almost ceased to grow at low iron concentrations, including $10,5 \mathrm{nmol} \bullet \mathrm{L}^{-1}$, and control group, which indicated that Thalassiosira weissflogii demand more iron than Phaeodactylum tricornutum to sustain cell division.

When studying effects of iron on the growth of diatoms, the researchers often made such a hypothesis that diatom growth rate was limited by iron, and biogenic silica production rates and cellular silicon content was controlled by a combined influence of both iron and silicate [7]. Our experiments further found the coupling effect of iron and silicate was closely related to the actual combination of temperature, salinity and illumination in the growing environments, and the combined effect of various conditional factors could be different due to different algae species and other environmental conditions. For instance, iron concentration, temperature, coupling interaction between temperature and iron concentration, coupling interaction temperature and light intensity were the major factors affecting final cell density of Phaeodactylum tricornutum, but no obvious interactions among salinity, light intensity, and silicate concentration were found in our experiments. Temperature and light intensity had an inhibitory coupling effect on the growth of Phaeodactylum tricornutum mainly because the dark respiration of algae was greatly enhanced under the combination of high temperature and strong illumination $[52,33]$. Our experiments also showed that the coupling of iron and silicate had an important influence on the growth of these two diatoms, even iron concentration itself could be acted as a separate influencing factor to control the final cell density of Phaeodactylum 
tricornutum. This promotive coupling effect of iron and silicate concentration on diatom Phaeodactylum tricornutum growth was even more pronounced at low temperatures.

Environmental conditions and their coupling effects also affected the efficiency of silicate utilization by diatom cells. However, the environmental factors and their coupling interaction that affecting silicate utilization and those affecting the growth of algae cells were different in some degree. Our experiments showed that temperature, concentration of iron, and concentration silicate were the main control factors affecting the algal silicate utilization, and for different algae, these three factors had different order of influence, and they have different forms of coupling. This indicated that in addition to the environmental temperature and the content of silicate itself, the content of iron in environment played an important role in controlling the silicate utilization by diatom cells in some degree. Temperature is undoubtedly considered to be the main factor affecting algae growth [53]. For diatom, temperature not only affects the growth and photosynthesis of algae cells, but also affects the synthesis and accumulation of chemical constituents in cells [12]. In addition, temperature has effects on the activity of enzyme in diatom cells, the uptake efficiency of nutrients and the cycle of cell division [6]. Diatom plays an important role in silicon recycle. Diatom uptake silicate mostly during the period of sub cells from new shell, which indicates that accumulation and storage of bio-silicon is not in the life cycle but in the process of cell wall formation [2]. Diatoms can accumulate large amounts of silicon, which can be between 30 and 350 times the silicate concentration of the medium therefore [51]. Coupling interaction of iron and silicate was testified to be an important controlling factor in bio-silicon synthesis by both Phaeodactylum tricornutum and Thalassiosira weissflogii in our experiments. Even for algae Thalassiosira weissflogii, in addition to being coupled with the silicate concentration, iron concentration itself also affected silicates utilization by algae cells. It has been testified that iron deficiency has an important effect on the growth and photosynthesis of phytoplankton by many laboratory experiments and the rich iron experiment in high-nutrient-low-chlorophyll (HNLC) oceans [25]. Iron deficiency will change the proportion of macronutrient uptake by phytoplankton, reducing the uptake of nitrogen and silicate uptake increased. At the same time, under the condition of iron deficiency, silicon will be utilized by the algae at a faster rate than nitrogen, eventually lead to the coupling effect of iron and silicate, resulting iron and iron co-limiting [26,17]. 'Diatoms will adapt to iron limiting condition by reducing the cell volume, the increase of diatom cell volume and thicken of diffusion boundary will change the nutrients uptake rate. Compared to carbon and nitrogen contents, silicon contents in diatom cells under iron deficiency condition will increase accordingly [36].

\section{Conclusion}

Different algae have different suitable habitat requirements, at the same time, the coupling between factors such as temperature, salinity, light intensity, silicate concentration, and iron concentration can vary depending on the algae. As our experiments revealed that diatoms Phaeodactylum tricornutum and Thalassiosira weissflogii had different temperature, silicate and iron contents requirements for optimal growth, although the concentration of iron has important influence on the growth of two kinds of algae and the utilization of silicate, the coupling action of iron concentration and silicate concentration is obvious in algal Thalassiosira weissflogii, but not in Phaeodactylum tricornutum. This indicates that although iron concentration may play an important role in limiting the growth of diatoms, the ways and degrees of limiting are different with different kinds of diatoms.

\section{Acknowledgement}

We thanked the anonymous reviewers for their very helpful comments. This work was supported by Basic Scientific Research Program from Ministry of science and technology, China (2017FY201403, 2010CB951201), Strategic Priority Research Program of the Chinese Academy of Sciences (XDA11020202, XDA11030103), and State Key Laboratory of Tropical Oceanography (LTO) project (Y5YQ191001).

\section{References}

1. Baloun AJ, Morse DE. Ionic control of settlement and metamorphosis in Larval Haliotis-Rufescens (Gastropoda). Biol Bull. 1984;167(1):124138.

2. Behrenfeld MJ, Worthington K, Sherrell RM, Chavez FP, Strutton $\mathrm{P}, \mathrm{McPhaden} \mathrm{M}$, et al. Controls on tropical Pacific Ocean productivity revealed through nutrient stress diagnostics. Nature. 2006;442(7106):1025-1028.

3. Bergquist BA, Wu J, Boyle EA. Variability in oceanic dissolved iron is dominated by the colloidal fraction. Geochimica et Cosmochimica Acta. 2007;71(12):2960-2974.

4. Boyd PW, Jickells T, Law CS, Blain S, Boyle EA, Buesseler KO, et al. Mesoscale iron enrichment experiments 1993-2005: synthesis and future directions. Science. 2007;315(5812):612-617.

5. Bruland KW, Donat JR, Hutchins DA. Interactive influences of bioactive trace-metals on biological production in oceanic waters. Limnology and Oceanography. 1991;36(8):1555-1577.

6. Brussaard CPD, Kuipers B, Veldhuis MJW. A mesocoms study of Phaeocystis globosa population dynamics: I. Regulation role of virus in bloom control. Harmful Algae. 2005;4(5):859-874.

7. Brzezinski MA, Jones JL, Demarest MS. Control of silica production by iron and silicic acid during the Southern Ocean Iron Experiment (SOFeX). Limnology and Oceanography. 2005;50(3):810-824.

8. Cavender-Bares KK, Mann EL, Chisholm SW, Ondrusek ME, Bidigare RR. Differential response of equatorial Pacific phytoplankton to iron fertilization. Limnology and Oceanography. 1999;44(2):237-246.

9. Coale KH, Johnson KS, Chavez FP, Buesseler KO, Barber RT, Brzezinski MA, et al. Southern Ocean iron enrichment experiment: carbon cycling in high- and low-Si waters. Science. 2004;304(5669):408-414.

10. Cullen JJ, Lesser MP. Inhibition of photosynthesis by ultraviolet radiation as a function of dose and dosage rate: results for a marine diatom. Marine Biology. 1991;111(2):183-190. 
11. De Baar HJW, Boyd PW, Coale KH, Landry MR, Tsuda A, Assmy P. Synthesis of iron fertilization experiments: From the Iron Age in the age of enlightenment. Journal of Geophysical Research. 2005;110(C9).

12. De Castro Araujo S, Garcia VMT. Growth and biochemical composition of the diatom Chaetoceros cf. Wighamii bright well under different temperature, salinity and carbon dioxide levels. I. Protein, carbohydrates and lipids. Aquaculture. 2005;246(1-4):405-412.

13. De La Rocha CL, Hutchins DA, Brzezinski MA, Zhang Y. Effects of iron and zinc deficiency on elemental composition and silica production by diatoms. Marine Ecology Progress Series. 2000;195:71-79.

14. Demaster DJ. The accumulation and cycling of biogenic silica in the Southern Ocean: revisiting the marine silica budget. Deep-Sea Research Part II-Topical Studies in Oceanography. 2002;49(16):31553167.

15. Field CB, Behrenfeld MJ, Randerson JT, Falkowski P. Primary production of the biosphere: integrating terrestrial and oceanic components. Science. 1998;281(5374):237-240.

16. Franck VM, Brzezinski MA, Coale KH, Nelson DM. Iron and silicic acid concentrations regulate Si uptake north and south of the Polar Frontal Zone in the Pacific Sector of the Southern Ocean. Deep-Sea Research Part II-Topical Studies in Oceanography. 2000;47(15-16):3315-3338.

17. Franck VM, Smith GJ, Bruland KW, Brzezinski MA. Comparison of sizedependent carbon, nitrate, and silicic acid uptake rates in high- and low-iron waters. Limnology and Oceanography. 2005;50(3):825-838.

18. Garcia N, Lopez-Elias JA, Miranda A, Martinez-Porchas M, Huerta N, Garcia A. Effect of salinity on growth and chemical composition of the diatom Thalassiosira weissflogii at three culture phases. Latin American Journal of Aquatic Research. 2012;40(2):435-440.

19. Geider RJ, La Roche J. The role of iron in phytoplankton photosynthesis, and the potential for iron-limitation of primary productivity in the sea. Photosynthesis Research. 1994;39(3):275-301.

20. Gordon RM, Martin JH, Knauer GA. Iron in northeast pacific waters. Nature. 1982;299:611-612.

21. Grasshoff K, Kremling K, Ehrhardt M. Methods of seawater analysis. Wiley -VCH. 1999:193-198.

22. Guillard RRL. Culture of phytoplankton for feeding marine invertebrates. Culture of marine invertebrate animals. 1975:29-60.

23. Guillard RR, Ryther JH. Studies of marine planktonic diatoms. I.Cyclotella nana Hustedt and Detonula confervacea (cleve) Gran. Canadian Journal of Microbiology. 1962;8:229-239.

24. Hoffmann LJ, Peeken I, Lochte K. Iron, silicate, and light co-limitation of three Southern Ocean diatom species. Polar Biology. 2008;31(9):10671080.

25. Hudson RJM, Morel FMM. Iron transport in marine-phytoplankton: kinetics of cellular and medium coordination reactions. Limnology and Oceanography. 1990;35(5):1002-1020.

26. Hutchins DA, DiTullio GR, Zhang Y, Bruland KW. An iron limitation mosaic in the California upwelling regime. Limnology and Oceanography. 1998;43(6):1037-1054.

27. Javaheri N, Dries R, Burson A, Stal LJ, Sloot PMA, Kaandorp JA. Temperature affects the silicate morphology in a diatom. Scientific Reports. 2015;5:11652.

28. Johnson KS, Gordon RM, Coale KH. What controls dissolved iron concentrations in the world ocean? Marine Chemistry. 1997;57(3-4):137161.
29. Khatoon H, Banerjee S, Yusoff FM, Shariff M. Effects of salinity on the growth and proximate composition of selected tropical marine periphytic diatoms and cyanobacteria. Aquaculture Research. 2010;41(9):1348-1355.

30.Knap A, Michael A, Close A, Ducklow H, Dickson A. Protocols for the Joint Global Ocean Flux Study (JGOFS) core measurements. JFOFS. Report Nr. 19, VI+170pp, 1996.Reprint of the IOC manuals and guides No.29, UNESCO1994, Paris.

31.Leblanc K, Hare CE, Boyd PW, Bruland KW, Sohst B, Pickmere S, et al. Fe and $\mathrm{Zn}$ effects on the $\mathrm{Si}$ cycle and diatom community structure in two contrasting high and low-silicate HNLC areas. Deep-Sea Research Part I-Oceanographic Research Papers. 2005;52(10):1842-1864.

32. Lenes JM, Darrow BP, Cattrall C, Heil CA, Callahan M, Vargo GA, et al. Iron fertilization and the Trichodesmium response on the West Florida shelf. Limnology and Oceanography. 2001;46(6):1261-1277.

33.Lombard F, Erez J, Michel E, Labeyrie L. Temperature effect on respiration and photosynthesis of the symbiont-bearing planktonic foraminifera Globigerinoides ruber, Orbulina universa, and Globigerinella siphonifera. Limnology and Oceanography. 2009;54(1):210-218.

34. Martin P, van der Loeff MR, Cassar N, Vandromme P, d'Ovidio F, Stemmann $L$, et al. Iron fertilization enhanced net community production but not downward particle flux during the Southern Ocean iron fertilization experiment LOHAFEX. Global Biogeochemical Cycles. 2013;27(3):871-881.

35. Milligan AJ, Varela DE, Brzezinski MA, Morel FOMM. Dynamics of silicon metabolism and silicon isotopic discrimination in a marine diatom as a function of pCO2. Limnology and Oceanography. 2004;49(2):322329.

36. Mills MM, Alderkamp AC, Thuroczy CE, et al., Phytoplankton biomass and pigment response to Fe amendments in the Pine Island and Amundsen polynyas. Deep-Sea Res. Part II-Top Stud Oceanogr. 2012;71-76:61-76.

37. Moore JK, Doney SC, Glover DM, Fung IY. Iron cycling and nutrientlimitation patterns in surface waters of the world ocean. Deep-Sea Research Part II-Topical Studies in Oceanography. 2001;49(1-3):463507.

38. Petrou K, Trimborn S, Rost B, Ralph PJ, Hassler CS. The impact of iron limitation on the physiology of the Antarctic diatom Chaetoceros simplex. Marine Biology. 2014;161(4):925-937.

39. Ragueneau 0, Treguer P. Determination of biogenic silica in coastal waters - applicability and limits of the alkaline digestion method. Marine Chemistry. 1994;45(1-2):43-51.

40. Ragueneau 0, Treguer P, Leynaert A, Anderson RF, Brzezinski MA, DeMaster DJ, et al. A review of the Si cycle in the modem ocean: recent progress and missing gaps in the application of biogenic opal as a paleoproductivity proxy. Global and Planetary Change. 2000;26(4):317365.

41. Raven JA. Predictions of $\mathrm{Mn}$ and Fe Use efficiencies of phototrophic growth as a function of light availability for growth and of $\mathrm{C}$ assimilation pathway. New Phytologist. 1990;116(1):1-18.

42. Raven JA, Geider RJ. Temperature and algal growth. New Phytologist. 1988;110(4):441-461.

43. Riedel GF, Nelson DM. Silicon uptake by algae with no known Si requirement .2. Strong Ph-dependence of uptake kinetic-parameters in 
Phaeodactylum-Tricornutum (Bacillariophyceae). Journal of Phycology. 1985;21(1):168-171.

44. Riegman R, Noordeloos AAM, Cad EGC. Phaeocystis blooms and eutrophication of the continental coastal zones of the North Sea. Marine Biology. 1992;112(3):479-484.

45. Sedwick PN, Blain S, Queguiner B, Griffiths FB, Fiala M, Bucciarelli E, Denis M. Resource limitation of phytoplankton growth in the Crozet Basin, Subantarctic Southern Ocean. Deep-Sea Research Part II-Topical Studies in Oceanography. 2002;49(16):3327-3349.

46. Sarthou G, Timmermans KR, Blain S, Paul Tréguer. Growth physiology and fate of diatoms in the ocean: a review. Journal of Sea Research. 2005;53(1-2):25-42.

47. Sunda WG, Huntsman SA. Interrelated influence of iron, light and cell size on marine phytoplankton growth. Nature. 1997;390:389-392.

48. Tappin AD, Millward GE, Statham PJ, Burton JD, Morris AW. Trace-metals in the Central and Southern North-Sea. Estuarine, Coastal and Shelf Science. 1995;41(3):275-323.
49. Timmermans KR, van der Wagt B, de Baar HJW. Growth rates, halfsaturation constants, and silicate, nitrate, and phosphate depletion in relation to iron availability of four large, open-ocean diatoms from the Southern Ocean. Limnology and Oceanography. 2004;49(6):21412151.

50.Timmermans KR, Veldhuis MJW, Brussaard CPD. Cell death in three marine diatom species in response to different irradiance levels, silicate, or iron concentrations. Aquatic Microbial Ecology. 2007;46:253261.

51.Treguer P, Nelson DM, Van Bennekom AJ, Demaster DJ, Leynaert A, Queguiner B. The silica balance in the world ocean: a reestimate. Science. 1995;268(5209):375-379.

52.Verity PG. Effects of temperature, irradiance, and day length on the marine diatom Leptocylindrus danicus Cleve. II. Excretion. Journal of Experimental Marine Biology \& Ecology. 1981;55(2-3):159-169.

53.Wang X, Tang KW, Wang Y, Smith WO. Temperature effects on growth, colony development and carbon partitioning in three Phaeocystis species. Aquatic Biology. 2010;9(3):239-249. 